\title{
Introduction into Italy of Gryon pennsylvanicum (Ashmead), an egg parasitoid of the alien invasive bug Leptoglossus occidentalis Heidemann
}

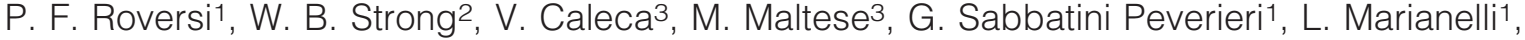 \\ L. Marziali1 and A. Strangi ${ }^{1}$ \\ ${ }_{1}(C R A-A B P)$ Agricultural Research Council, Agrobiology and Pedology Research Centre, Via di Lanciola 12/a, Cascine del Riccio, \\ 50125 - Florence (Italy); e-mail: piofederico.roversi@entecra.it \\ ${ }^{2}$ BC Ministry of Forests, Lands, and Mines, Kalamalka Forestry Centre, 3401 Reservoir Rd, Vernon, BC V1B 2 C7 (Canada) \\ ${ }^{3}$ University of Palermo, Dipartimento SENFIMIZO, Viale delle scienze, Edificio 5, 90128 Palermo (Italy)
}

\begin{abstract}
Leptoglossus occidentalis (Heteroptera, Coreidae), a Nearctic species, was accidentally introduced into Northern Italy in the late 1990s, from where it has spread throughout Europe. The bug causes abortion of immature cones of Pinus pinea L., with economic impact on the pine-nut industry. As part of a pest control research program, the egg parasitoid Gryon pennsylvanicum Ashmead (Hymenoptera, Platygastridae) was collected from British Columbia, Canada, and legally introduced to a quarantine climatic chamber in Florence, Italy. The egg parasitoid will be tested against native nontarget heteropterans, an environmental impact assessment will be conducted, and a mass rearing method will be developed if appropriate. The ultimate goal is to release $G$. pennsylvanicum into Italian $P$. pinea forests for classical biological control of $L$. occidentalis.
\end{abstract}

\section{Introduction}

Leptoglossus occidentalis Heidemann (Heteroptera Coreidae) (Fig. 1) (Western Conifer Seed Bug), originally described from adults collected in California and Utah (Heidemann, 1910), belongs to the Western fauna and is widely distributed from Canada to Mexico (Hedlin et al., 1981; Cibrian-Tovar et al., 1986).

Additional records have shown an eastward extension of the range in the Nearctic area and the capability to colonize new host, including Scotch pine (Pinus sylvestris) and the Austrian pine (Pinus nigra) (McPherson et al., 1990). Leptoglossus occidentalis is a common and important pest in conifer seed orchards of lodgepole pine (Pinus contorta var. latifolia Engelmann), western white pine (Pinus monticola Dougl. ex D. Don), Douglas fir [Pseudotsuga menziesii (Mirbel) Franco], reducing seed crops by feeding on ovules and seeds within the cones (Koerber, 1963; Bates et al., 2000, 2002; Strong et al., 2001). In 1999 this invasive alien pest was first recorded from Northern Italy (Lombardia and Veneto regions) (Villa et al., 2001), from where it quickly spread to many mountain and coastal pine woods along the Italian peninsula and in the largest islands (Sicilia and Sardegna) (Bernardinelli \& Zandigiacomo, 2002; META, 2004; Roversi, 2006; Maltese et al., 2009; Santini, 2010). It has now been detected across Europe: from Turkey to Portugal, and from Sicily to Norway (Jucker et al., 2009; OEPP/EPPO, 2010). Both the expansion of the range until the Atlantic coast of USA and Canada and the recent establishment in short time in most of the European countries suggest that its impact on natural regeneration, reforestation programmes and pine nut production may increase.

\section{Pest significance and economic impact in Pinus pinea L. forests}

The Italian stone pine (Pinus pinea L.), a conifer that requires 3 years to complete cone development, grows across an area of approximately 20000 hectares. At the end of 1990s the total weight of pine cones for pine nut production for food was about 40000 tonnes per year. Since the introduction of $L$. occidentalis into Italy, production of pine nuts has decreased rapidly, not only in Italy but also in other European areas (Roversi, 2009), and in 2009 cone harvests declined by as much as 95\% from Italian stone pine forests.

One preliminary study carried out in 2005 in central Italy (Toscana) in the Regional Natural Park of Migliarino - S. Rossore Massaciuccoli using staining techniques and antibody-based tests (Campbell \& Shea, 1990; Bates et al., 2002) showed that immature cones of stone pine abort in response to feeding by L. occidentalis and over $60 \%$ of 1-year-old conelets (Fig. 2) and $80 \%$ of 2 -year-old conelets were compromised by the exotic bug (Roversi et al. unpubl. data).

\section{Biological control of Western Conifer Seed Bug}

The new alien-species invasion led the Italian Ministry of Agricultural, Food and Forestry Policies to activate a specific research program aimed to clarify L. occidentalis biology in Mediterranean environments and to develop pest control strategies (Niccoli et al., 2009). We report on our project in the field of biological control of the pest by the use of egg parasitoids native to North 


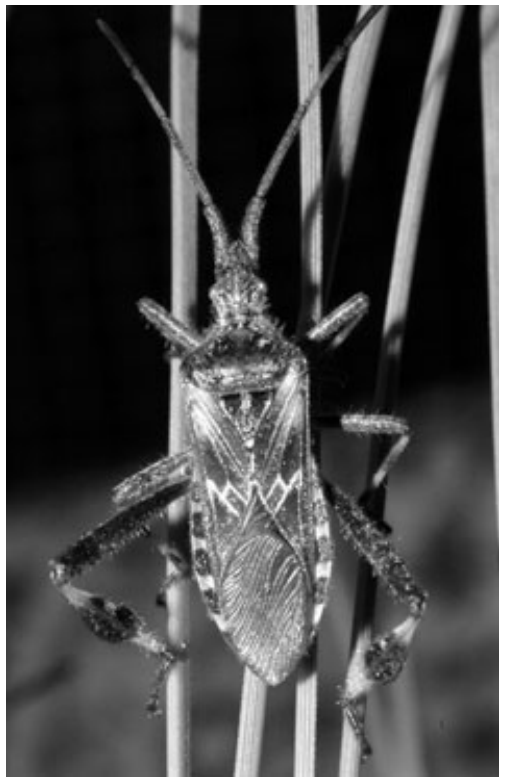

Fig. 1 Adult Leptoglossus occidentalis: note the short and foliaceous expansion of hind tibiae.

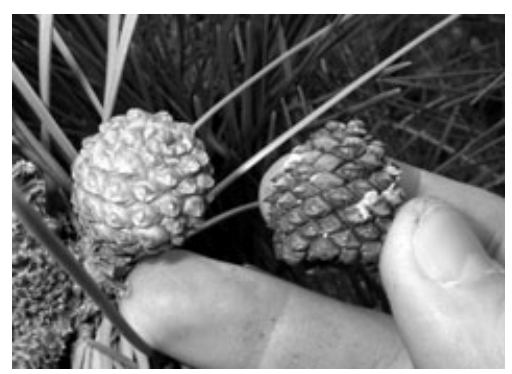

Fig. 2 Pinus pinea: healthy and aborted 1-year-old conelets.

America (National Project 'PINITALY - The restart of Pine Nuts production in Italy by new pest control strategies', DM 256/7303/2007).

This project began in 2009 with a collaboration programme among Italian entomologists (CRA - ABP, Agrobiology and Pedology Research Centre, Firenze and University of Palermo) and Canadian entomologists (Kalamalka Forestry Center, Ministry of Forests \& Range, British Columbia). Their major objective was to find out the most competitive egg parasitoid of L. occidentalis and then introduce it into Italy from its native area, start a mass production laboratory, and test the parasitoid against potential non-target heteropteran hosts in Italy. The ultimate goal is to evaluate the parasitoid's environmental impact and efficacy in $P$. pinea stands in controlling $L$. occidentalis population levels.

Based on literature available on L. occidentalis, Gryon pennsylvanicum (Ashmead) (Hymenoptera, Platygastridae), a natural egg parasitoid from North America, was considered a possible biological control agent.

A rearing methodology was created in the Italian laboratories for obtaining L. occidentalis egg clusters all year around, using conifer seeds and potted pine plants as food. During 2010 G. pennsylvanicum was obtained from L. occidentalis eggs collected in British Colombia and, with the authorization of the Italian Ministry (DG COSVIR 0013900) and of the Tuscan Regional Phytosanitary Service (Prot. 42073), parasitized eggs were introduced to the CRA-ABP laboratory in Florence.

A colony of $G$. pennsylvanicum has now been established in Florence in a climatic chamber, using $L$. occidentalis eggs as host (Fig. 3). In October 2010 trials began to determine a mass-rearing technique to obtain egg parasitoid adults to be used in future biological control programs.

\section{Identity of the Western Conifer Seed Bug egg parasitoid introduced in Europe}

Name: Gryon pennsylvanicum (Ashmead)

G. pennsylvanicum belongs to the floridanum-group, the members of this group of species are the largest of the genus (Masner, 1983; Mineo \& Caleca, 1987); it is an egg parasitoid of largesized members of the family Coreidae such as Leptoglossus clypealis Heidemann, L. corculus (Say), L. gonagra (Fabr.), L. phyllopus (L.), Anasa tristis (De G.), Narnia femorata Stal, N. pallidicornis Stal (Masner, 1983; Yasuda \& Tsurumachi, 1995; Mitchell et al., 1999). All of these hosts are not native to Europe and they, as well as their eggs, are much larger than those of several European Coreidae.

Gryon pennsylvanicum is quite common and widely distributed across the Southern and Midwestern regions of the United States. Yasuda \& Tsurumachi (1995) found highly parasitized L. australis eggs by G. pennsylvanicum in Japan, also.

The only data about its parasitism on $L$. occidentalis eggs were obtained in British Columbia (Canada) by Bates \& Borden

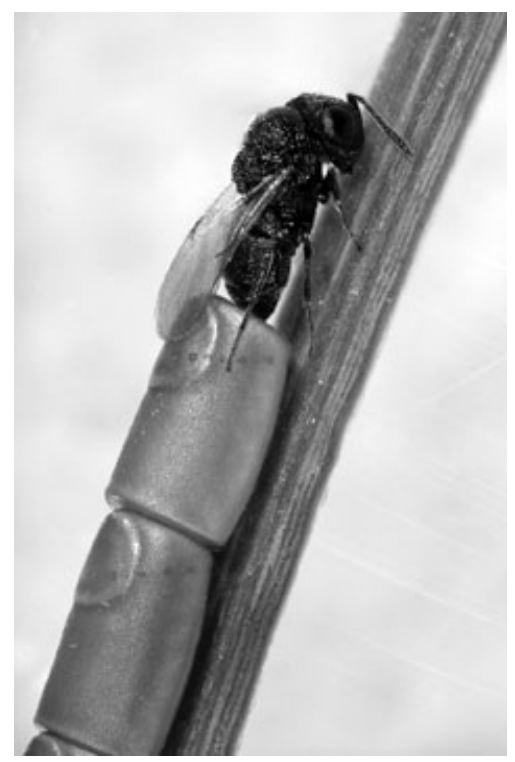

Fig. 3 Female Gryon pennsylvanicum ovipositing in Western Conifer Seed Bug eggs. 
(2004). These data showed that G. pennsylvanicum is the predominant parasitoid attacking $87 \%$ of parasitized eggs.

\section{Acknowledgements}

This work was supported by the Italian Ministry of Agricultural, Food and Forestry national project 'PINITALY - The restart of the Pine Nuts production in Italy by new pest control strategies', DM 256/7303/2007.

\section{Introduction en Italie de Gryon pennsylvanicum (Frênemead), un parasitoïde des œufs de la punaise envahissante Leptoglossus occidentalis Heidemann}

Leptoglossus occidentalis (Heteroptera, Coreidae), une espèce néarctique, a été accidentellement introduite dans le nord de l'Italie à la fin des années 1990, puis s'est disséminée dans l'ensemble de l'Europe. Cette punaise provoque l'avortement des cônes immatures de Pinus pinea L., ce qui a un impact économique pour l'industrie des pignons de pin. Dans le cadre d'un programme de recherche sur les méthodes de lutte, le parasitoïde des œufs Gryon pennsylvanicum Ashmead (Hymenoptera, Platygastridae) a été collecté en Colombie-Britannique, Canada, et introduit légalement dans une chambre climatique de quarantaine à Florence, Italie. Ce parasitoïde sera testé contre hétéroptères indigènes, une évaluation de l'impact environnemental sera menée, et une méthode d'élevage de masse sera développée. L'objectif final est de relâcher G. pennsylvanicum dans les forêts italiennes de $P$. pinea pour assurer une lutte biologique classique contre $L$. occidentalis.

\section{Интродукция в Италию Gryon pennsylvanicum Ashmead - паразитоида яиц чужеродного инвазивного клопа Leptoglossus occidentalis Heideman}

Leptoglossus occidentalis (Heteroptera, Coreidae), неарктический вид, был случайно завезен в Северную Италию в конце 1990-ых годов, и оттуда распространился по всей Европе. Этот клоп вызывает опадание незрелых шишек Pinus pinea L. и оказывает экономическое воздействие на производство орешков этой сосны. Являясь составной частью программы исследований по борьбе с вредными организмами, паразитоид яиц Gryon pennsylvanicum Ashmead (Hymenoptera, Platygastridae) был собран в Британской Колумбии (Канада), и, в соответствии с существующим законом, был интродуцирован в карантинную климатическую камеру во Флоренции (Италия). Паразитоид яиц будет проверен на его побочное воздействие на аборигенных клопов, не являющихся мишенями. Будет оценено его воздействие на окружающую среду, а также будет разработан метод его массового разведения. Конечной целью является выпуск $G$. pennsylvanicum в итальянские леса $P$. pinea с целью классической биологической борьбы с L. occidentalis.

\section{References}

Bates SL, Borden JH, Kermode AR \& Bennet RG (2000) Impact of Leptoglossus occidentalis (Hemiptera: Coreidae) on Douglas-Fir Seed Production. Journal of Economic Entomology 93(5), 1444-1451.

Bates SL, Strong WB \& Borden JH (2002) Abortion and seed set in Lodgepole and Western White Pine Conelets following feeding by Leptoglossus occidentalis (Heteroptera: Coreidae). Environmental Entomology 31(6), 1023-1029.

Bates SL \& Borden JH (2004) Parasitoids of Leptoglossus occidentalis Heidemann (Heteroptera: Coreidae) in British Columbia. Journal of the Entomological Society of British Columbia 101, 143-144.

Bernardinelli I \& Zandigiacomo P (2002) First record of conifer seed bug (Leptoglossus occidentalis) in Friuli Venezia Giulia. Notiziario ERSA 15(5), 44-46.

Campbell BC \& Shea PJ (1990) A simple staining technique for assessing feeding damage by Leptoglossus occidentalis Heidemann (Hemiptera: Coreidae) on cones. Canadian Entomologist 122(9-10), 963-968.

Cibrian-Tovar DB, Hebel BH, Yates HO \& Mendez-Montiel JT (1986) Leptoglossus occidentalis Heidemann. In: Cone and Seed Insects of the Mexican Conifers (Eds Cibrian-Tovar DB, Hebel BH, Yates HO \& Mendez-Montiel JT), pp. 55-58, USDA Forest Science, Southeastern Forest Experiment Station, Ashville (US).

Hedlin AF, Yates HO, Tovar DC, Ebel BH, Koerber TW \& Merkel EP (1981) Cone and Seed Insects of North American Conifers. Canadian Forestry Service, USDA and Forest Service and Secretaria de Agricultura y Recursos Hidraulicos, Mexico, 122

Heidemann O (1910) New species of Leptoglossus from North America (Hemiptera; Coreidae). Proceedings of the Entomological Society of Washington 12, 191-197.

Jucker C, Niccoli A \& Roversi PF (2009) Leptoglossus occidentalis Heidemann. Cimice americana delle conifere. In Insetti Esotici e Tutela Ambientale (Eds Jucker C, Barbagallo S, Roversi PF \& Colombo M), pp. 52-55. Arti Grafiche Maspero Fontana, Cermenate, Italy (in Italian).

Koerber TW (1963) Leptoglossus occidentalis (Hemiptera: Coreidae), a newly discovered pest of coniferous seed. Annals of the Entomological Society of America 56, 229-234.

Maltese M, Caleca V \& Carapezza A (2009) Primi reperti in Sicilia su diffusione e biologia di Leptoglossus occidentalis Heidemann (Heteroptera: Coreidae), cimice americana dei semi delle conifere. In: Proceedings: III Congresso Nazionale di Selvicoltura per il miglioramento e la conservazione dei boschi italiani, pp. 1413-1418. (in Italian).

Masner L (1983) A revision of Gryon Haliday in North America (Hymenoptera: Proctotrupoidea: Scelionidae). Canadian Entomologist 115, 123-174.

McPherson JE, Packauskas RJ, Taylor SJ \& O’Brien MF (1990) Eastern range extension of Leptoglossus occidentalis with a key to Letptoglossus species of America North of Mexico (Heteroptera: Coreidae). The Great Lakes Entomologist 23(2), 99-104.

META-Phytosanitary Monitoring Program of Forests in Tuscany (2004) Arrivato in Toscana un nuovo insetto dannoso ai semi delle conifere. http://meta.arsia.toscana.it/meta/meta?id_cms_doc=1\&id_news=115 (in Italian), website accessed on October 20, 2010.

Mineo G \& Caleca V (1987) Remarks on the species of Gryon Haliday of the floridanum-group with description of a new species (Hym. Proctotrupoidea: Scelionaidae). Phytophaga 2, 31-40.

Mitchell PL, Paysen ES, Muckenfuss AE, Schaffer M \& Shepard BM (1999) Natural mortality of Leaf footed Bug (Hemiptera: Heteroptera: Coreidae) eggs in Cowpea. Journal of Agricultural and Urban Entomology 16(1), 25-36.

Niccoli A, Benassai D, Croci F \& Roversi PF (2009) Anastatus bifascaitus ooparassitoide di Leptoglossus occidentalis. Proceedings XXII Congresso Nazionale Italiano di Entomologia, 337 (in Italian). 
OEPP/EPPO Reporting Service - Pests \& Diseases (2010) Leptoglossus occidentalis: an invasive alien species spreading in Europe. http:// archives.eppo.org/EPPOReporting/2010/Rse-1001.pdf.

Roversi PF (2006) Avversità degli alberi e delle foreste. In: AA.VV. RAFT 2005 Rapporto sullo stato delle foreste in Toscana. ARSIA. Sherwood 124 (7/06), suppl. n. 2, 128 (in Italian).

Roversi PF (2009) Adattamento di specie neo-introdotte. Leptoglossus occidentalis Heidemann. In Insetti esotici e tutela ambientale. (Eds Jucker C, Barbagallo S, Roversi PF \& Colombo M), pp. 224-229, Arti Grafiche Maspero Fontana, Cermenate, Italy (in Italian).

Santini L (2010) La cimice americana delle conifere (Leptoglossus occidentalis Heidemann) (Heteroptera, Coreidae) e fruttificazione del pino domestico. Supplemento a "I Georgofili. Atti dell'Accademia dei Georgofili", Anno 2009 (Serie VIII) 6, 15-36 (in Italian).
Strong WB, Bates SL \& Stoehr M (2001) Feeding by Leptoglossus occidentalis (Hemiptera: Coreidae) reduces seed set in lodgepole pine (Pinaceae). The Canadian Entomologist 133, 857-865.

Villa M, Tescari G \& Taylor SJ (2001) Nuovi dati sulla presenza in Italia di Leptoglossus occidentalis (Heteroptera: Coreidae). Bollettino della Società Entomologica Italiana 133(2), 101-112.

Yasuda K \& Tsurumachi M (1995) Influence of male adults of the LeafFooted Plant Bug, Leptoglossus australis (Fabricius) (Heteroptera: Coreidae), on host-aearching of the egg parasitoid, Gryon pennsylvanicum (Ashmead) (Hymenoptera: Scelionidae). Applied Entomology and Zoology 30(1), 139-144. 